\title{
IMPLEMENTASI FITUR LAYER 7 PROTOCOLS MIKROTIK RB750 DI SMKN 1 NARMADA
}

\author{
Muhammad Husnaini' ${ }^{1}$, Wire Bagye ${ }^{2}$, Maulana Ashari ${ }^{3}$ \\ 1Teknik Informatika, STMIK Lombok \\ Jln. Basuki Rahmat No. 105 Praya Lombok Tengah 83511 - Praya \\ 12oneajyad@gmail.com, ${ }^{2}$ wirestmik@gmail.com, 3 aarydarkmaul@gmail.com
}

\section{Abstract}

Internet Users Teachers and students at SMK Narmada 1, 75 - 85\% access the internet for social media, download games, watch videos, complete assignments from subject teachers. The results of observations and interviews at Narmada 1 Vocational High School show sites that are often accessed by Narmada 1 Vocational High School students are sites outside of learning content, such as Facebook, Youtube and several gaming sites.

To maximize the use of the internet for students to access lessons it is necessary to do majamen in order to access students on certain sites. The new network configuration is done by implementing the Layer 7 Protocol feature on the proxy RB750 in the filter rule feature, access list. The researcher applied the NDLC method in the development of network systems, deactivating the network system which then added the RB750 router and accesspotint as media access using wi-fi.

The results of the Implementation of Proxy Servers with Layer 7 Features of the RB750 Microtic Protocol in Narmada Vocational High School 1 proved to be able to block the desired sites such as facebook, youtube and online games wrongly mobilelegends games and other sites that use the https protocol. Besides that, also applying this proxy does not affect the speed or bandwidth of the internet connection in Narmada 1 Vocational School.

Keywords: Proxy Server, Layer 7, NDLC, SWOT, Mirkotik RB750

\section{Abstrak}

Pengguna Internet Guru dan siswa di SMKN 1 Narmada, 75 - 85 \% mengakses internet untuk sosial media, mendownload game, menonton video, menyelesaikan tugas dari guru mata pelajaran. Hasil observasi dan wawancara di SMKN 1 Narmada menunjukan bahwa situs yang sering diakses khususnya oleh siswa SMKN 1 Narmada adalah situs di luar konten pembelajaran, seperti Facebook, Youtube dan beberapa situs game.

Untuk memaksimalkan penggunaan internet bagi siswa untuk mengakses pelajaran maka perlu dilakukan majamen jaringan guna membatasi akses siswa pada situs tertentu. Konfigurasi jaringan baru dilakukan dengan mengimplementasikan sebuah fitur Layer 7 Protocols yang terdapat pada mikrotik RB750 pada feature Filter rules, access list. Peneliti menerapkan metode NDLC dalam pengmbangan sistem jaringan, disain sistem jaringan yang ada kemudian menambahkan router RB750 dan aksespotint sebagai media akses menggunakan wi-fi.

Hasil Implementasi Proxy Server dengan Fitur Layer 7 Protocols Mikrotik RB750 di SMKN 1 Narmada terbukti mampu melakukan bloking terhadap situs-situs yang diinginkan seperti facebook, youtube dan game online salah satunya game mobilelegends serta situs - situs lain yang menggunakan protocol https. Disamping itu juga penerapan proxy ini tidak mempengaruhi kecepatan atau bandwidth dari koneksi internet yang ada di SMKN 1 Narmada.

Kata Kunci : Proxy Server, Layer 7, NDLC, SWOT, Mikrotik RB750

ISSN. 2620-6900 (Online) 2620-6897 (Cetak) 


\section{PENDAHULUAN}

Pengguna Internet baik Guru dan siswa khususnya di SMKN 1 Narmada dengan jumlah Guru sebanyak 72 orang dan siswa pada Tahun Pelajaran 2017 / 2018 ini mencapai 600 siswa, dari kelas X s/d XII semua jurusan, 75 - $85 \%$ pernah mengakses internet, mulai dari mengakses sosial media, mendownload game, menonton video hingga untuk keperluan tugas dari guru mata pelajaran. Dari hasil observasi dan wawancara di SMKN 1 Narmada, situs yang sering diakses khususnya oleh siswa SMKN 1 Narmada adalah situs di luar konten pembelajaran, seperti Facebook, WhatsApp, Youtube dan beberapa situs permainan lainnya.

Oleh karena itu perlu adanya sebuah sistem yang akan mengatur konfigurasi server internet di sekolah, seperti menerapkan network police supaya penggunaan internet disekolah lebih baik, dengan cara membatasi pengaksesan beberapa situs seperti Facebook, Youtube, game online dan lain-lain Penerapan konfigurasi pada server internet disekolah, memiliki dampak yang sangat positif seperti siswa secara langsung akan dipaksa untuk mengakses situs pembelajaran lebih banyak lagi dikarenakan situs yang biasa dibuka sudah di blokir pengaksesanya oleh server.

\section{PUSTAKA DAN TEORI}

\section{A. Tinjauan Pustaka}

Peningkatan akses Internet merupakan misi setiap lembaga namun efek dari peningkatan akses Internet dapat menambah beban web server. Beban pada web server yang paling tinggi saat penggunaan video live streming. Hal lainnya ialah Padatnya lalu lintas jaringan untuk men-transfer data/berkas, dan lamanya waktu transfer sebagai akibat padatnya lalu lintas jaringan. Upaya penyelesaian dilakukan dengan implementasi proxy server videocache. Dilakukan optimalisasi penyimpanan video menggunakan videocache pada proxy server squid menggunakan aplikasi videocach. Berdasarkan hasil uji coba menggunakan black box test dapat disimpulkan bahwa aplikasi ini dapat diterapkan pada salah satu warnet yang ada di Yogyakarta yaitu Janturan.NET[4].

Penelitian Manajemen Jaringan berbasis Mikrotik RouterOSTM pada Badan Narkotika
Nasional (BNN). Badan Narkotika Nasional (BNN) proses perkembangannya khususnya dalam bidang jaringan Komputer membutuhkan konfigurasi terbaru. Pada penelitian ini menggunakan Mikrotik RouterOSTM menggunakan Graphic User Interface (GUI) melalui fasilitas Winbox sehingga lebih User friendly. Metode pengembangan system menggunakan metode Network Development Life Cycle (NDLC). NDLC mendeskripsikan konfigurasi jaringan komputer yang berkelanjutan yang mencakup tahap Analisis, Design, Simulation Prototype, Implementation, Monitoring dan Managemen. kesimpulan hasil dari penelitiannya biaya untuk membangun jaringan dengan mikrotik mempunyai harga yang relatif murah dan semua Jaringan komputer baik wireless dan kabel dapat dimanajemen dengan mikrotik. Pembagian Bandwidth internet dengan mikrotik memberikan efisiensi pemakaian bandwidth internet dan istem keamanan jaringan yang diberikan oleh mikrotik dapat terfasilitasi dengan baik [2]

Wireless Application Protocol (WAP) merupakan suatu protocol yang memungkinkan internet dapat diakses dengan perangkat mobile seperti ponsel atau handphone dan perangkat wireless lainnya. Data menunjukkan bahwa total seluruh penduduk di Indonesia menggunakan handphone seluler 70\%. Data dari Asosiasi Telepon Seluler (ATSI), penduduk Indonesia sudah menjadi pelanggan seluler sekitar 180 juta. Untuk memaksimalkan fungsi dari perpustakaan maka diimplementasikan teknologi informasi dengan memanfaatkan layaan WAP. Manfaat implementasi WAP pada Perpustakaan dengan membangun system informasi maka user mengakses katalog di perpustakaan dengan menggunakan Handphone ataupun Iphone dengan lebih mudah. Selain itu perpustakaan berbasis digital dapat menciptakan kerjasama perpustakaan antar universitas lain atau perpustakaan nasional[1].

Implementasi perangkat Network Attached Storage STMIK Lombok untuk pengelolaan file yang dikelola pada komputer terpisah. Berdasarkan kebutuhan media penyimpanan data pada jaringan di STMIK Lombok maka dirancang arsitektur jaringan dengan memanfaatkan perangkat Network Attached Storage dengan fokus pada penyimpanan cepat 
dan transfer data. Tahapan penelitian meliputi pengumpulan data, desain, dan metode pengujian Untuk dapat membantu menyelesaikan masalah akses data yang terpisah maka diimplementasikan Network Attached Storage (NAS). Dengan menghubungkan computer pengolah data melalui jaringan local sehingga data terpusat pada computer server yang terpasang perangkat Network Attached Storage untuk manajemen file. Hasil pengujian dapat disimpulkan bahwa FreeNas sebagai sistem operasi yang digunakan untuk pemrosesan media penyimpanan jaringan sangat mampu menangani tugas dengan baik dan fasilitas yang ada di dalamnya sangat mendukung dalam penyimpanan dan mengakses file[3].

\section{B. Network Development Life Cycle (NDLC)}

Network Development Lifecyle (NDLC) merupakan suatu metode yang digunakan dalam mengembangakan atau merancang topologi jaringan yang memungkinkan terjadinya pemantauan jaringan untuk mengetahui statistik dan kinerja jaringan. Hasil dari analisis kinerja menjadi pertimbangan perubahan model jaringan yang meliputi desain jaringan fisik atau jaringan logis seperti skema routing, pengalamatan jaringan, prioritas lalu lintas data, keamanan dan manajemen. tahapan NDLC sebagai berikut[8]:

1. Analisis Tahap awal ini dilakukan analisa kebutuhan, analisa permasalahan yang muncul, analisa keinginan pengguna, dan analisa topologi / jaringan yang sudah ada saat ini. Biasanya metode yang digunakan seperti wawancara, survei dll.

2. Desain Tahap Desain ini akan membuat gambar desain topologi jaringan interkoneksi yang akan dibangun, diharapkan dengan gambar ini akan memberikan gambaran seutuhnya dari kebutuhan yang ada. Desain bisa berupa desain struktur topologi, desain akses data, desain tata layout perkabelan, dan sebagainya yang akan memberikan gambaran jelas tentang proyek yang akan dibangun.

3. Simulasi/Prototipe Beberapa teknisi jaringan akan membuat dalam bentuk simulasi dengan bantuan Tools khusus di bidang network seperti BOSON, PACKET TRACERT, NETSIM, dan sebagainya, hal ini dimaksudkan untuk melihat kinerja awal dari jaringa yang akan dibangun dan sebagai bahan presentasi dan sharing dengan team work lainnya.

4. Implementasi Di tahapan ini akan memakan waktu lebih lama dari tahapan sebelumnya. Dalam implementasi teknisi jaringan akan menerapkan semua yang telah direncanakan dan di desain sebelumnya.

5. Monitoring Setelah implementasi tahapan monitoring merupakan tahapan yang penting, agar jaringan komputer dan komunikasi dapat berjalan sesuai dengan keinginan dan tujuan awal dari pengguna pada tahap awal analisis, maka perlu dilakukan kegiatan monitoring.

6. Manajemen Di manajemen atau pengaturan, salah satu yang menjadi perhatian khusus adalah masalah aturan, kebijakan perlu dibuat untuk membuat / mengatur agar sistem yang telah dibangun dan berjalan dengan baik dapat berlangsung lama dan unsur reliability terjaga.

7.

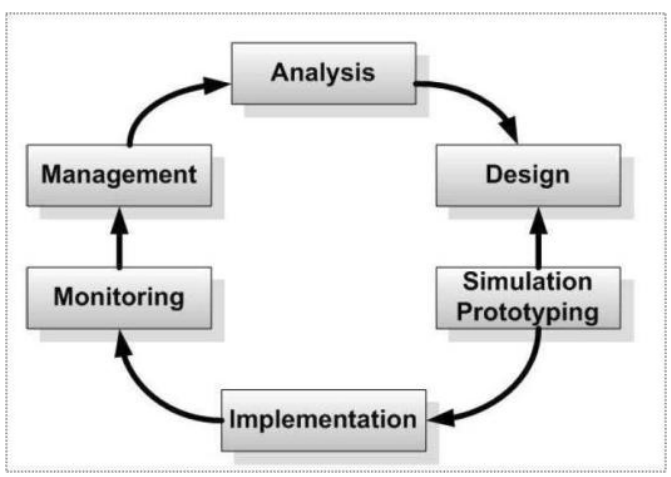

Gambar 3.1 Metode NDLC system

\section{Layer 7 Protocol}

Layer 7 Protocol adalah layer aplikasi yang Berfungsi sebagai antarmuka dengan aplikasi dengan fungsionalitas jaringan, mengatur bagaimana aplikasi dapat mengakses jaringan, dan kemudian membuat pesan-pesan kesalahan. Protokol yang berada dalam lapisan ini adalah HTTP, FTP, SMTP, dan NFS. Cara kerja L7 adalah 
mencocokan (mathcer) 10 paket koneksi pertama atau 2KB koneksi pertama dan mencari pola/pattern data yang sesuai dengan yang tersedia. Jika pola ini tidak ditemukan dalam data yang tersedia, matcher tidak memeriksa lebih lanjut. Dan akan dianggap unknown connections. Anda harus mempertimbangkan bahwa banyak koneksi secara signifikan akan meningkatkan penggunaan memori pada RB maupun PC Router anda. Untuk menghindari itu tambahkan regular firewall matchers (pattern) untuk mengurangi jumlah data yang dikirimkan ke layer-7 filteR[5].

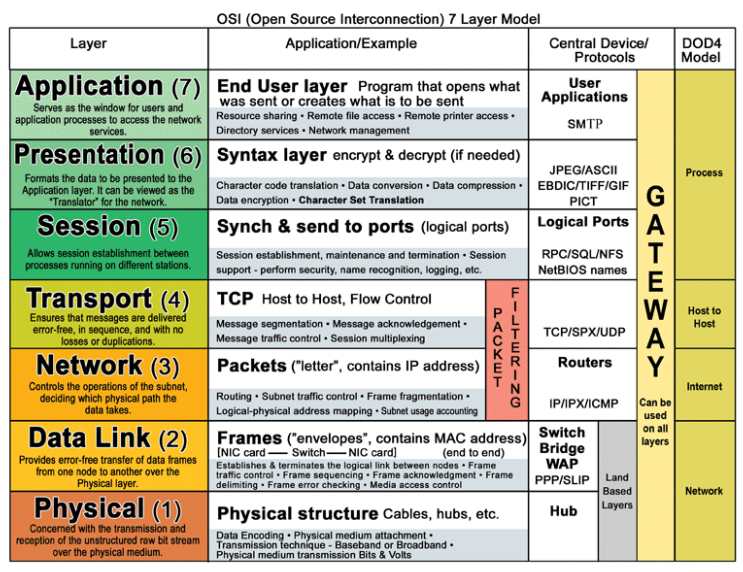

Gambar. 2.1. Layer lapisan OSI

\section{Analisis SWOT}

Teori SWOT (Strengths- WeaknessesOpportunities- Threats) menurut Wheelen dan Hunger[6]. Merupakan sebuah langkah untuk dapat mengidentifikasi faktor internal dan eksternal yang berpengaruh terhadap pencapaian tujuan organisasi. Lingkungan eksternal berisi variabel peluang dan ancaman (oppoturnities and threats) yang berada di luar organisasi dan bukan merupakan hal yang dapat dikontrol oleh pimpinan organisasi dalam jangka waktu dekat. Lingkungan internal organisasi terdiri dari variabel kekuatan dan kelemahan (strenghts and weaknesses) yang berada dalam tubuh organisasi itu sendiri dan biasanya tidak dalam kontrol pimpinan organisasi dalam waktu dekat. Yang termasuk dalam variabel ini adalah struktur, budaya, dan sumber daya organisasi.

Analisa SWOT menggunakan Balanced Score Card yang bertujuan untuk mengetahui informasi strategis apa saja yang harus dikumpulkan sebelum menyusun SWOT Balance Scorecard [7]. Sebelum mulai menyususn SWOT Balance Score card kumpulkan semua informasi strategis yang dibutuhkan dalam penyusunana SWOT Balance Scorecard untuk Informasi yang berhubungan dengan perusahaan ialah:

1. Rencana Strategis dibandingkan dengan kondisi saat ini

2. Rencana finansial dibandingkan dengan kondisi saat ini

3. Rencana pemasaran dibandingkan dengan kondisi saat ini

4. Rencana pengoperasian dibandingkan dengan kondisi saat ini

5. Laporan tahunan

6. Program peningkatan kualitas

7. Anlisis pelanggan

8. Wawancara dengan manajemen eksekutif

9. Dokumen oerencanaan penunjanag lainnya

\section{METODOLOGI PENELITIAN}

\section{A. Analisa}

Analisa dilkukan untuk mengukur tingkat kesiapan dan potensi implementai layer 7 untuk manajemen jaringan di SMKN 1 Narmada. Analisa dilkukan untuk kebutuhan implemetasi dan pengujian manajemen jaringan yang baru sehingga dapat dialkukan perncangan, pengembangan dan pengujian yang tepat.

Tabel 3.1 Analisa SWOT

\begin{tabular}{|c|c|c|c|}
\hline No. & Analisa & Faktor Internal & Eksternal \\
\hline 1 & Strength & $\begin{array}{l}\text { Jumlah siswa SMKN } 1 \\
\text { Narmada Jumlah } \\
\text { Jurusan dan Prodi } \\
\text { SMKN 1 Narmada } \\
\text { Fasilitas Internet }\end{array}$ & $\begin{array}{l}\text { Pengguna } \\
\text { dari luar } \\
\text { lingkungan } \\
\text { sekita } \\
\text { SMKN 1 } \\
\text { Narmada }\end{array}$ \\
\hline 2 & Weakness & $\begin{array}{l}\text { Kurangnya } \\
\text { jangkauan Internet } \\
\text { Keamanan Jaringan } \\
\text { yang sangat lemah }\end{array}$ & $\begin{array}{l}\text { Bandwitdh } \\
\text { terbatas }\end{array}$ \\
\hline 3 & Opportunities & $\begin{array}{ll}\text { Penerapan } & \text { Proxy } \\
\text { Server } & \\
\end{array}$ & \\
\hline 4 & Threats & \begin{tabular}{lr}
\multicolumn{2}{l}{ Tenaga } \\
dan Taninistrasi \\
SMKN 1 Narmada \\
Pro dan & Kontra \\
terhadap & \\
Pengembangan \\
\multicolumn{2}{l}{ Sistem } \\
\end{tabular} & \\
\hline
\end{tabular}




\section{B. Sistem Jaringan Baru}

Rancangan topologi jaringan yang Peneliti bangun dengan menggunakan Server Proxy yaitu tidak jauh berbeda dengan topologi sebelumnya (tanpa server proxy) hanya saja ada penambahan server proxy kurang lebih sebagai berikut:

1. Sinyal internet dari ISP (Indihome)

2. Sinyal internet di teruskan ke Mikrotik Rb750.

3. Dari mikrotik Rb750 kemudian diteruskan ke switch hub melali port Ethernet 1.

4. Sedangkan untuk aksespoint digunakan port 5 yang ada pada mikrotik Rb750.

5. Mikrotik Rb750 digunakan untuk mengatur Proxy dengan menu layer 7 ptocols sesuai dengan kebutuhan, adapun jenis pengaturannya

6. Blok Konten

Mikrotik juga salah satu media yang Peneliti gunakan untuk melakukan blok konten / memblok suatu situs / website yang sekiranya tidak menunjang proses nelajar mengajar siswa di SMKN 1 Narmada seperti : Facebook, Youtube, Game Online.

7. SwithHub

Mikrotik dihubungkan dengan Swith Hub, yang mana Swith Hub memiliki fungsi untuk menggabungkan beberapa komputer menjadi satu buah kelompok jaringan. Dengan mengunkan kabel UTP yang diseting secara straight yang dihubungkan ke LAN Card dengan $\mathrm{Rj} 45$.

7. Aksess Point

Setelah Server Proxy di hubungkan ke Mikrotik selanjutnya Mikrotik dihubungkan dengan Akses point TP_link untuk pengaksesan oleh siswa melalui perangkat w-fi yang terdapat pada perangkat Laptop atau anroid.

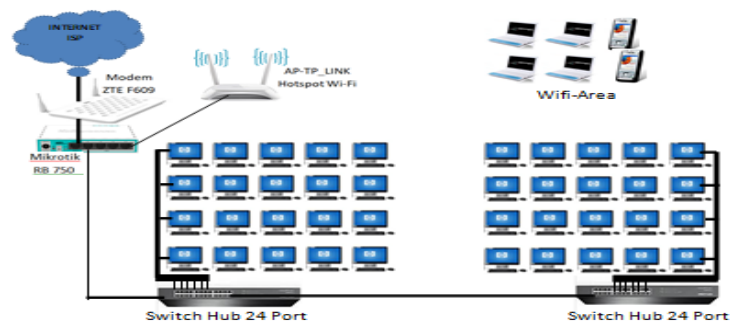

Gambar 3.2 Rencana Topologi Jaringan SMKN Narmada

\section{HASIL DAN PEMBAHASAN}

Pada tahapan implementasi perangkat lunak, dibutuhkan aplikasi winbox, web browser, dan sistem operasi mikrotik. Dengan menggunakan routerboard, maka sistem operasi mikrotik sudah terinstal didalamnya. Selanjutnya konfigurasi awal mikrotik dilakukan dengan aplikasi winbox. Sedangkan web browser dapat digunakan untuk konfigurasi mikrotik setelah melakukan konfigurasi awal dengan winbox.

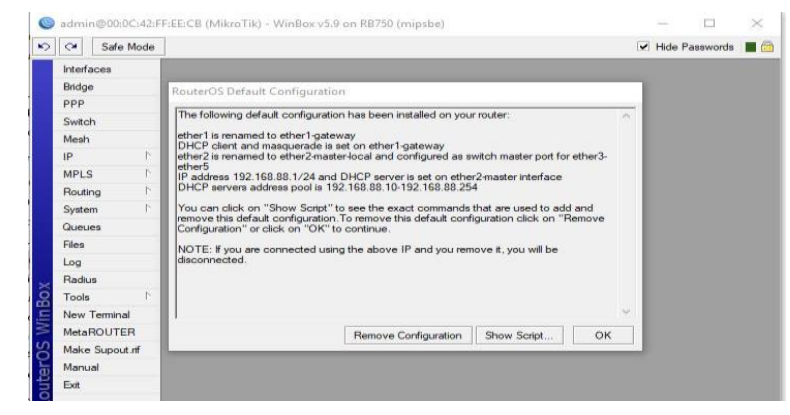

Gambar 4.1. Tampilan Menu Mirotik

\section{A. Instalasi Winbox}

Aplikasi winbox digunakan untuk mengkonfigurasi routerboard mikrotik dari PC client. Aplikasi ini dapat didownload secara gratis di situs mikrotik Indonesia dengan alamat situs (http://www.mikrotik.co.id/download.php). Setelah winbox di-jalankan, mac address dan IP dari routerboard mikrotik akan tampil otomatis, jika topologi jaringannya sudah tepat.

\section{B. Konfigurasi Interface}

Pada menu interface ini Peneliti akan menggunakan 3 ethernet untuk masing-masing port yang ada pada routerboard. Interfacenya terdiri dari

1. Interface untuk ether1Internet pada port 1

2. Interface untuk ether2_Lokal pada port 2

3. Interface untuk ether5_Hotspot pada port 5

Pada Address List klik tanda plus merah isikan new Address kemudian isikan IP Address sesuai kebutuhan, seperti :

- IP 192.168.1.2/24 ; untuk jaringan / Modem Internet:

- IP. 192.168.88.0/24; untuk Jairngan Lokal / Swicth; dan 
- IP. 192.168.150.1/24; untuk Jairngan Hotspot; Langkah ini dilakukan pada setiap pembuatan alamat IP kemudian >> klik $O K$,

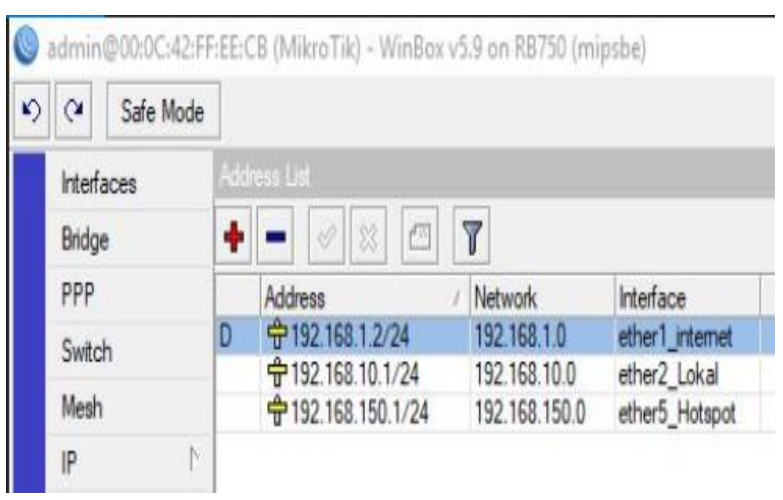

Gambar 4.2. Konfigurasi IP Address

\section{Konfigurasi Hotspot Mikrotik}

Untuk mengkonfigurasi hotspot pada mikrotik RB 750, tahapan awal yang harus dilakukan adalah mengkonfigurasi Wireless Accespoint terlebih dahulu kemudian menghubungkan wireless acccespoint ke perangkat mikrotik. Dilanjutkan dengan mengkonfigurasi hotspot pada mikrotik.

\section{Konfigurasikan Access Point}

Hubungkan Access point ke PC client dengan kabel UTP, Restart network kemudian masuk ke browser. pada Address bar masukan IP Access Point tadi, IP access point 192.168.0.1, Login Access point. Untuk username masukan admin, dan untuk password juga masukan admin.

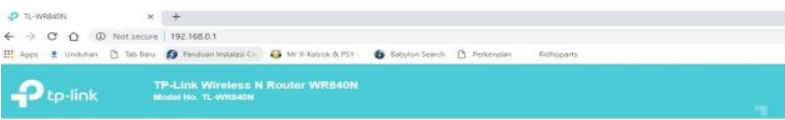

Gambar 4.3 Login Akses Point

Selanjutnya masuk ke fitur dimana untuk mengkonfigurasikan Access point. Klik Next pada Quick Setup untuk mulai

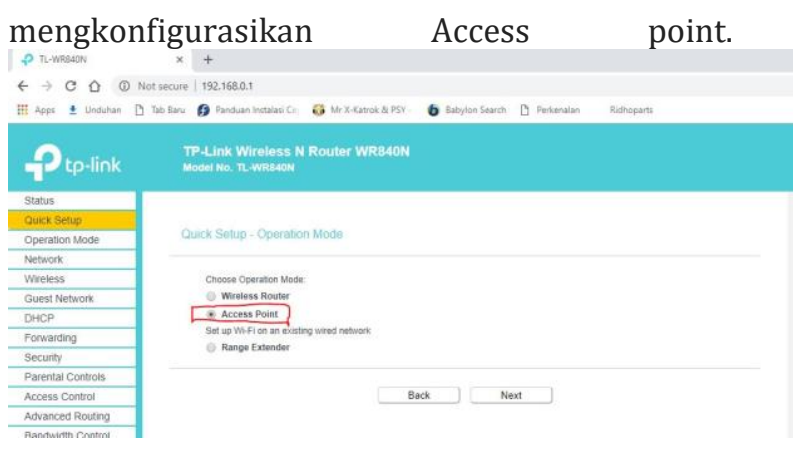

Gambar 4.4. Konfigurasi Setup Akses Point

Pilih Access point apabila terdapat pilihan seperti berikut. pada penulisan SSID dan penulisan Password disini Peneliti tidak melakukan karena akan di setting pada konfigurasi hotspot di mikrotik yang nantinya akan diakses oleh klient.

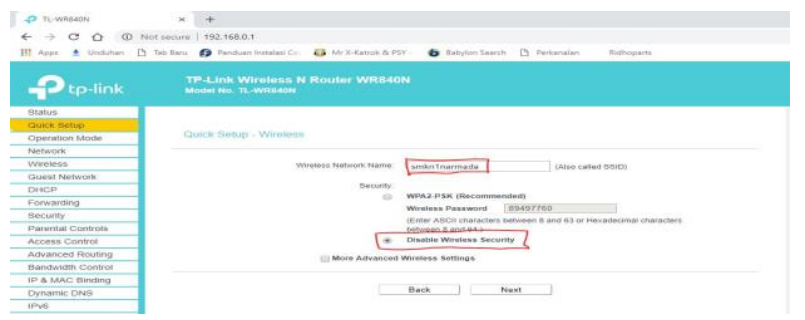

Gambar 4.5. Pengaktipan Akses Point

Masukan IP baru untuk Access point kita, disini Peneliti menggunakan IP 192.168.150.1 dan Netmask-nya adalah 255.255.255.0. dan Pada DHCP kita pilih disable.

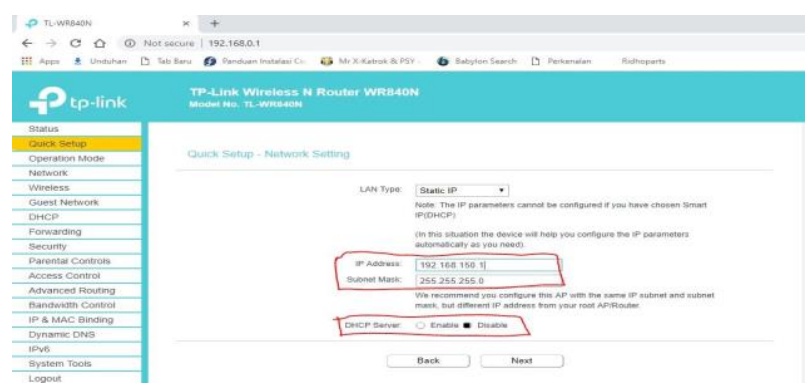

Gambar 4.6. Konfigurasi IP Address dan DHCP Selesai konfigurasi Access Point, selanjutnya klik reboot untuk memaksimalkan konfigurasi atau pengaturan yang sudah dilakukan 


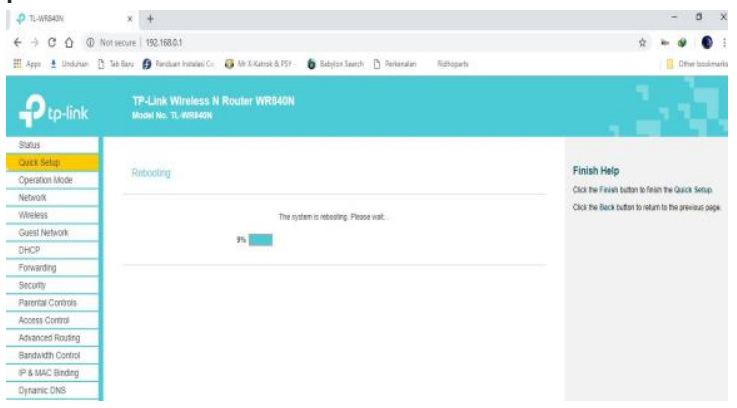

Gambar 4.7. Reboot Setup Akses Point.

\section{E. Konfigurasi Hotspot pada Mikrotik}

Masuk ke Winbox pada PC Client yg sudah terhubung ke Mikrotik. Coonect menggunakan IP atau Mac Address yang terdeteksi kemudian klik

connect

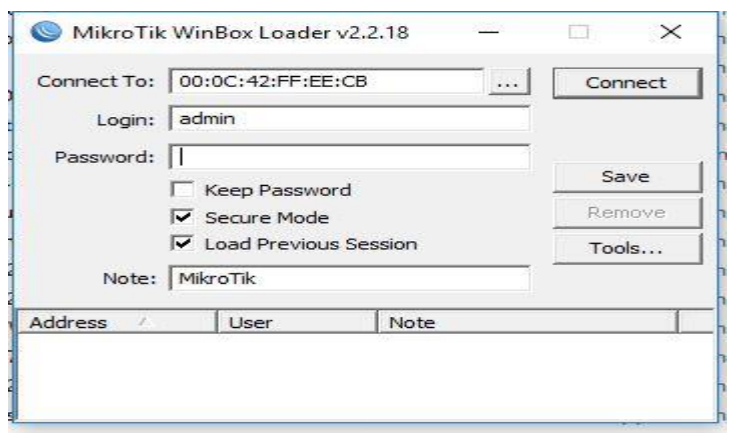

Gambar 4.8. Login Mikrotik

\section{F. Setting Hotspot}

Setelah proses konfigurasi dasar seperti pengisian IP address dan Netmask selesai dilakukan, Selanjutnya membuat Hotspot pada Mikrotik dengan cara masuk ke Menu IP-> Hotspot. Lalu klik Hotspot Setup.

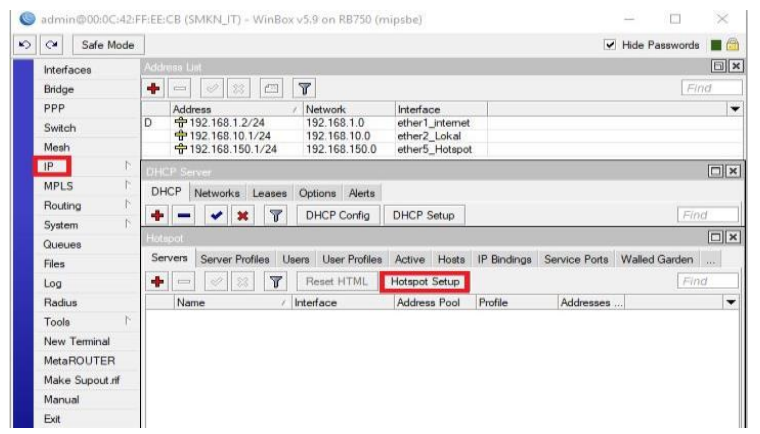

Gambar 4.9 Konfigurasi Hotspot
1. Pilih Ether yang terhubung ke Access point pada Hotspot Interface, Karena Ether yang terhubung ke Access Point adalah Ether 5, maka Pilih Ether5_Hotspot Klik Next

Pada Set HotSpot addreess for interface klik Next saja karena IP sudah terisi otomatis. Klik next

2. Pada Set pool for HotSpot addreess juga klik Next saja karena pool sudah terisi otomatis.

3. Pada Select hotspot ssl certificate pilih yang None, kemudian klik Next.

4. pada Select

SMTP

Server masukan 0.0.0.0Pada Setup DNS

Configuration klik next saja apabila sudah terisi otomatis

5. Pada menu DNS name of local hotspot server masukan sebuah URL yang akan di gunakan sebagai halaman login di web browser nantinya.

6. Selanjutnya Pada Create Local Hotspot user, masukan username dan password yang digunakan untuk mengakses hotspot nantinya, user bisa ditambah dan diatur apabila Hotspot sudah berhasil.

\section{G. Konfigurasi Proxy Server}

Pada penelitian kali ini Peneliti menggunakan fitur layer 7 dikarenakan fitur ini memiliki kelebihan untuk melakukan blokir situs https.

Blokir Situs dengan Layer 7 Protocols (L7P) Pertama yang harus dilakukan untuk blokir situs https adalah membuat sebuah scripts blokir situs di layer 7 protocols, berikut caranya :

1. Membuka Layer 7 Protocols

Untuk membuka fitur L7P, klik menu IP > Firewall, lalu pilih tab Layer 7 Protocols (Tab paling kanan)

1. Membuat script L7P

Untuk membuat konfigurasi / script baru, klik tanda + Biru, lalu isi kolom Name dengan "ditolak" script dan Regexp : ^.+(situsdiblok1.com|situsdiblok2.com).*\$, contohnya disini saya memblok facebook, youtube. dan mobilelegen.com Jika sudah Klik OK 


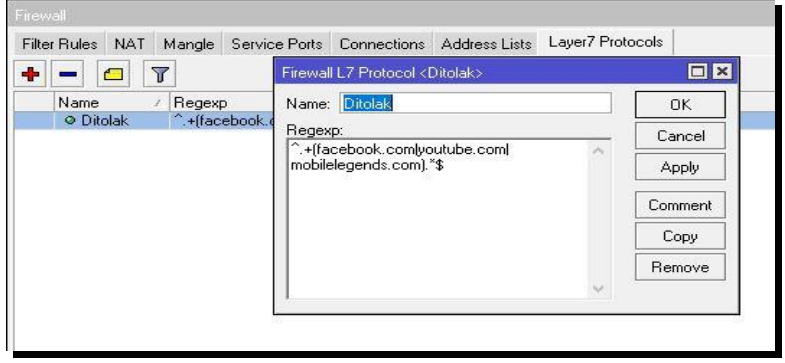

Gambar 4.10 Konfigurasi Layer7 Protocol

Membuat Filter Rules | Tab General Setelah membuat script L7P, langkah berikutnya membuat filter rules / aturan untuk menjalankan script L7P, Klik menu IP > Firewall lalu pada tab Filter Rules klik tanda + untuk membuat konfigurasi baru, pada tab general isi kolom chain forward

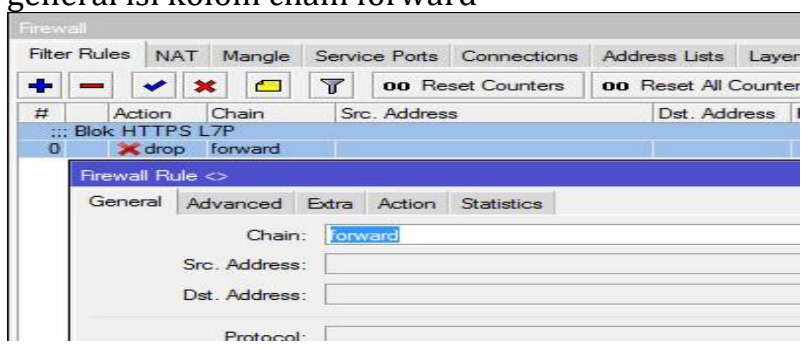

Gambar 4.11 Konfigurasi Chain Layer7 Protocol

Tab Advanced Pada tab Advanced, isi kolom layer7 Protocols dengan nama script L7P yang telah di buat sebelumnya.

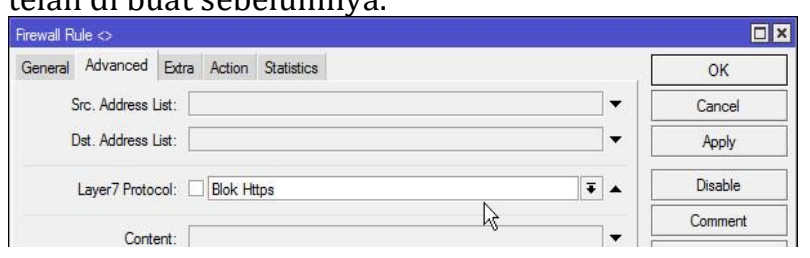

Gambar 4.12 Konfigurasi Advance Layer7 Protocol

Tab Action Sedangkan pada tab action pilih Drop, dan jika klik OK

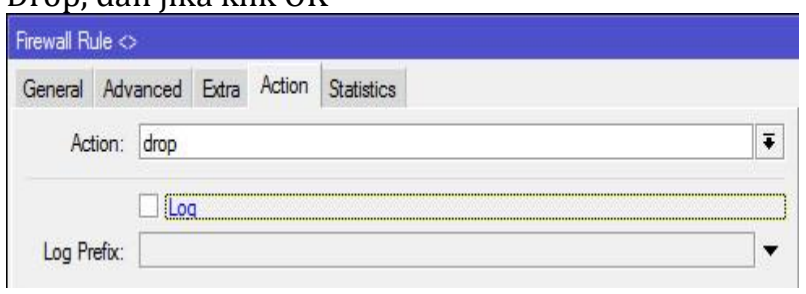

Gambar 4.13 : Konfigurasi Action Layer7

Protocol
Setiap user yang mengakses situs yang telah di tuliskan pada L7P (Tab Advanced) maka akan diarahkan (Chain : Forward) dengan aksi di blokir (Action : Drop)

\section{H. login Hotspot}

Untuk dapat menggunakan koneksi Internet, para siswa harus melakukan tahapan seperti berikut :

a. Mengaktifkan Wi-fi, kemudian memilih Hotspot "smkn1narmada" selanjutnya klik connect.

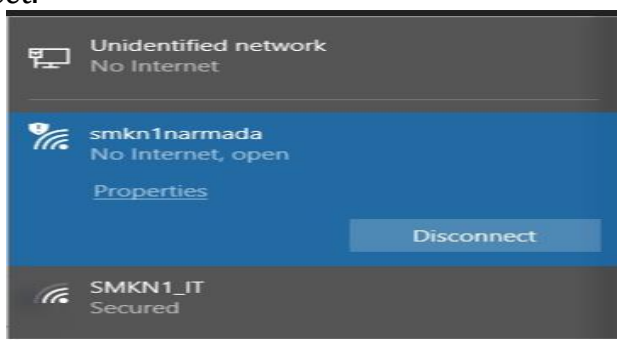

Gambar 3.14 Tampilan Hotspot yang aktif

b. Selanjutnya buka halaman web browser, ketikkan IP 192.168.150.1 pada menu Seacrh Bar selanjtnya klik Enter.

c. Selanjutnya masukkan username "admin" dan password "123" Enter,

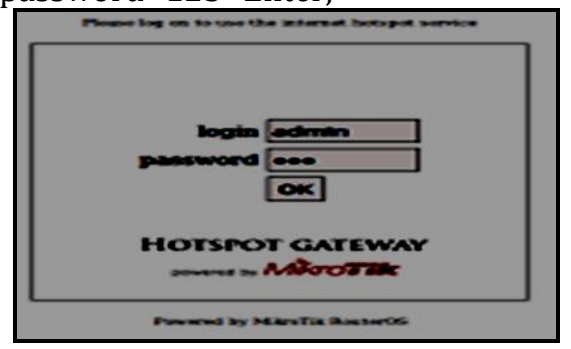

Gambar 4.15 Tampilan Login Mikrotik

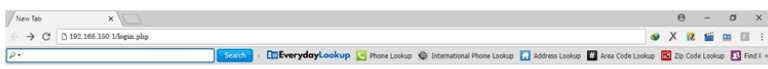

Welcome admin!

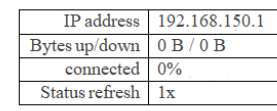

$\log$ off

Gambar 4.16 Tampilan IP yang aktip

d. Membuka situs sebelum dijalankan proxy contoh situs game online yaitu www.mobilelegends.com 


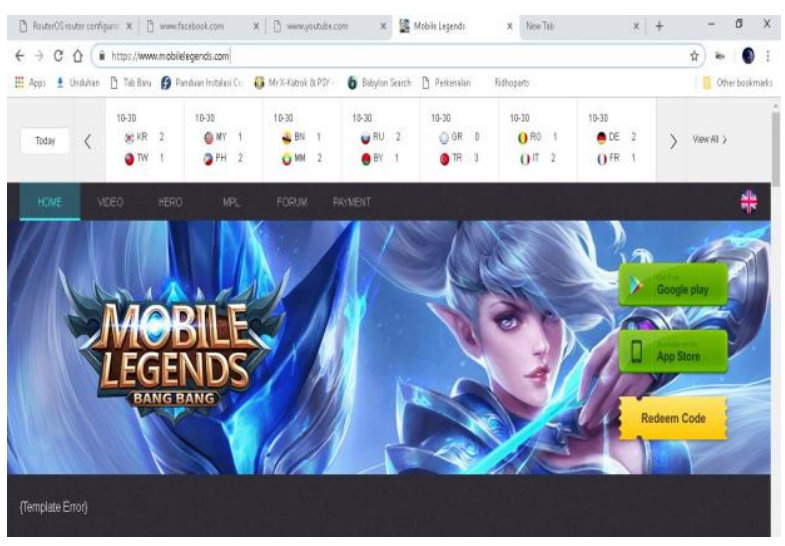

Gambar 4.17 Situs Mobilelegends sebelum proxy

\section{Mebuka Situs Yang di Blokir}

Setelah login dan mendapat koneksi internet, untuk menguji apakah proxy yang sudah dibuat diatas berjalan atau tidak. Buka situs - situs yang dimasukkan pada fitur layer 7 protocols yaitu : facebook.com, youtube.com dan mobilelegends.com akan terlihat seperti gambar 4.18 .

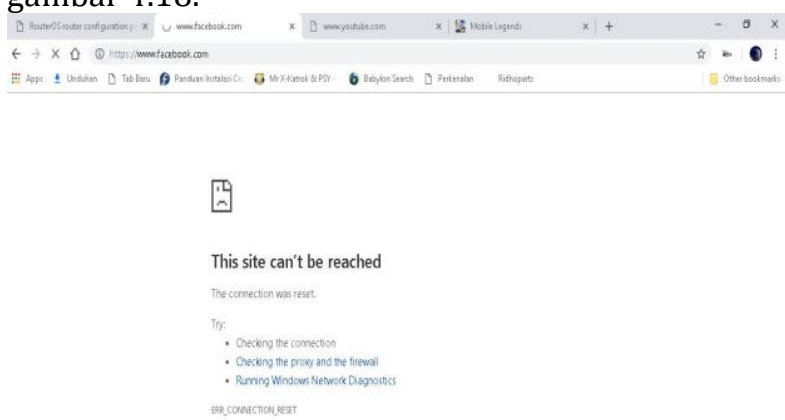

Gambar 4.18 Tampilan Situs Facebook diblokir

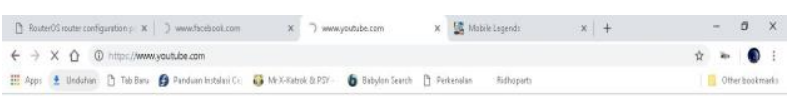

圆

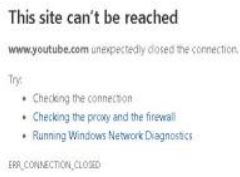

Gambar 4.19 Tampilan Situs Youtube diblokir

ISSN. 2620-6900 (Online) 2620-6897 (Cetak)

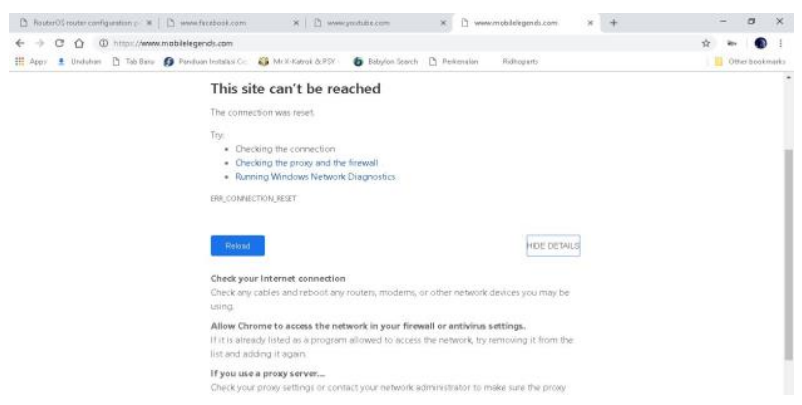

Gambar 4.20 Tampilan Situs mobilelegends diblokir

\section{J. Monitoring}

Monitoring diperlukan untuk memantau aktivitas berjalan atau tidaknya sebuah konfigurasi pada router mikrotik, fitur atau menu yang kita bisa gunakan adalah menu filter list yang ada pada menu IP >> Firewall >> Filter rule.

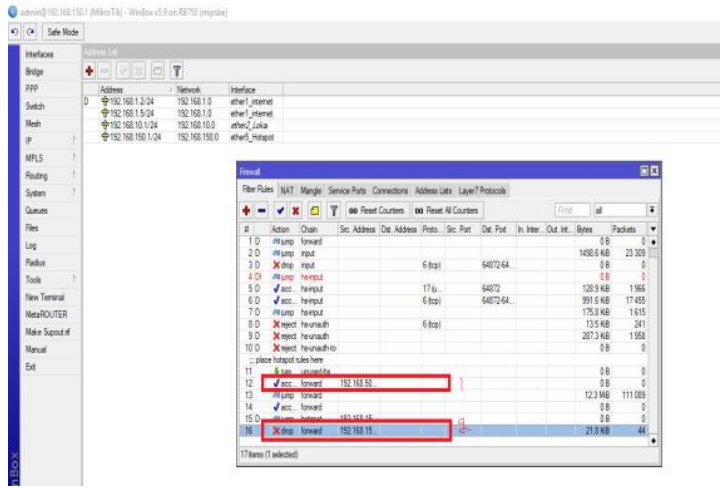

Gambar 4.21 Filter List Firewall

Pada baris pertama menunjukkan sebelum dilakukan proxy dan baris kedua IP akan memiliki status drop pada saat situs tersebut dibuka atau diaktifkan. Penerapan proxy server dengan layer 7 protocols tidak memberikan pengaruh apapun terhadap kecepatan dan bandwidth koneksi internet di SMKN 1 Narmada, seperti pada tampilan test kecepatan dengan tools speedtest berikut ini : 


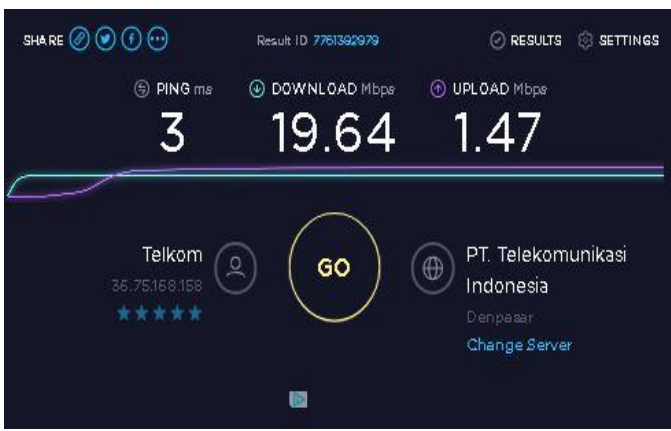

Gambar 4.22 Speed test Internet

\section{K. Hasil}

Secara keseluruhan dari mulai perancangan, implementasi dan pengujian proxy server dengan fitur layer 7 protocols dapat berfungsi dengan baik seperti yang terlihat pada menu conection yang berisi daftar situs yang diakses. Situs yang diblok akan menampilan keterangan established.

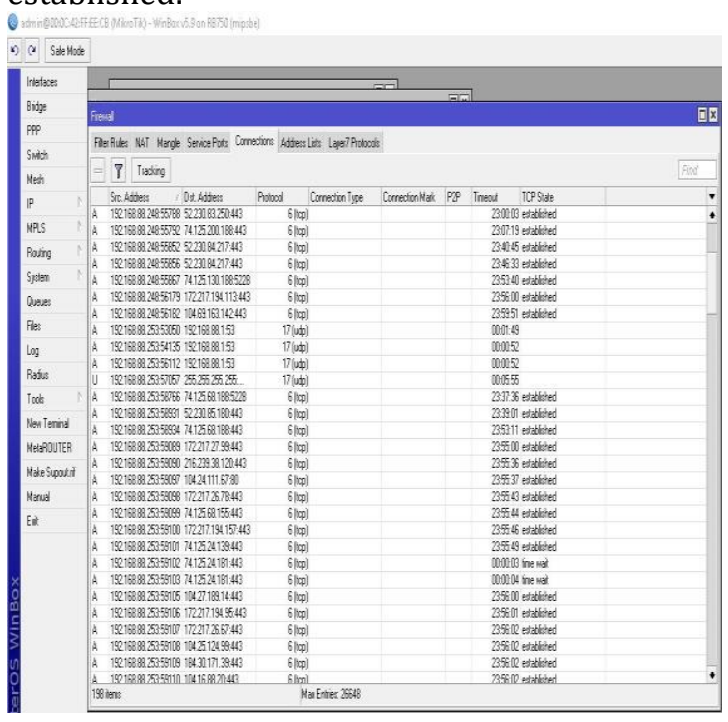

Gambar 4.23 Daftar Situs yang sedang di akses5.

\section{KESIMPULAN DAN SARAN}

\section{A. Kesimpulan}

Hasil Analisa dan Implementasi Proxy Server dengan Fitur Layer 7 Protocols Mikrotik RB750 di SMKN 1 Narmada terbukti mampu melakukan bloking terhadap situs-situe yang diinginkan seperti facebook, youtube dan game online salah satunya game mobilelegends serta situs - situs lain yang menggunakan protocol https. Disamping itu juga penerapan proxy ini tidak mempengaruhi kecepatan atau bandwidth dari koneksi internet yang ada di SMKN 1 Narmada, ini terlihat pada gambar 4.36, hasil test koneksi dengan menggunakan tool Speedtest dari google drive.

\section{B. Saran}

Pada penelitian selanjutnya untuk membangun sebuah system yang memiliki tingkat keamanan yang tinggi seperti Pembagian bandwidth dan integrasi jaringan lebih dari satu titik akses serta control managemet lainya. sehingga kecendrungan untuk mengakses situs sosmed, video dan game online dapat turun secara maksimal, dengan demikian penggunaan dan pemampaatan internet $100 \%$ untuk kepentingan proses belajar dan mengajar siswa dilingkungan SMKN 1 Narmada.

\section{Daftar Pustaka}

[1] Afrina, Mira, and Ali Ibrahim. "Pengembangan Model Sistem Informasi Perpustakaan dengan Teknologi Informasi Berbasis Wireless Aplication Protocol (WAP) pada Universitas Sriwijaya." Jurnal Sistem Informasi 4.1 (2012).

[2] Anwar, Nanang Khaerul. "Analisis dan perancangan manajemen jaringan dengan menggunakan mikrotik routerOS tm (study kasus: Badan Norkotika Nasional)." (2010).

[3] Kalaena, Lalu Supriadi, and Wire Bagye. "Implementasi Network Attached Storage (NAS) Menggunakan Freenas Pada STMIK Lombok." Jurnal Manajemen Informatika dan Sistem Informasi 1.1 (2018): 6-10.

[4] Listyawan, Nunung Budi, and Imam Riadi. "Optimalisasi Penyimpanan Video Menggunakan Videocache pada Proxy Server (Studi Kasus pada Warnet Janturan. net YOGYAKARTA)." Jurnal Sarjana

[5] Teknik Informatika 1.2: 634646.Patwiyanto, S.Kom.. (2017). Administrasi Sistem Jaringan Buku Pegangan Guru Edisi Revisi 2017. ANDI AFFSET. Yogyakarta.

[6] Mulyanta, Edi S. Pengenalan Protokol Jaringan Wireless Komputer. Penerbit Andi, 2005. Mulyanta, Edi S. Pengenalan Protokol Jaringan Wireless Komputer. Penerbit Andi, 2005 
[7] Rangkuti, Freddy. Analisis SWOT teknik membedah kasus bisnis. Gramedia Pustaka Utama, 1998.

[8] Rangkuti, Freddy. SWOT-BALANCED SCORECARD. Gramedia Pustaka Utama, 2013.
[9] James E. Goldman, P. T. (2004). Chapter 10 : The Network Development Life Cycle. Dalam Applied Data Communications: A BusinessOriented Approach (hal. 375). 